Section Editor Mitchell S.V. Elkind, MD, MS

\title{
Emerging Subspecialties in Neurology: Autonomic disorders
}

Jose-Alberto Palma, MD, $\mathrm{PhD}$

Glen A. Cook, MD

Mitchell G. Miglis, MD

Adam Loavenbruck, MD

Correspondence to

Dr. Palma:

JoseAlberto.PalmaCarazo@

nyumc.org
Autonomic nervous system (ANS) dysfunction as a cause of disease is an increasingly recognized health problem, not only in the field of neurology, but also in cardiology, gastroenterology, endocrinology, urology, psychiatry, and primary care medicine. Patients may present with a myriad of symptoms including orthostatic intolerance, recurrent syncope, labile blood pressure, disorders of sweating and thermoregulation, neurogenic bladder, sexual dysfunction, gastrointestinal dysmotility, pupil abnormalities, and sleep disorders. These symptoms may, in turn, be a consequence of genetic (e.g., hereditary sensory and autonomic neuropathies, transthyretin amyloidosis), neurodegenerative (e.g., Parkinson disease [PD], multiple system atrophy [MSA]), autoimmune (e.g., autoimmune ganglionopathies), or acquired disorders (e.g., spinal cord lesions, type 2 diabetes). Although autonomic symptoms may be among the most debilitating features of these progressive conditions, they are often treatable. Autonomic disorders specialists require a comprehensive knowledge of the anatomy, physiology, and pharmacology of the ANS, understanding of the pathophysiology and management of acute and chronic autonomic conditions, and expertise in the performance and interpretation of clinical and laboratory evaluation of the ANS.

Historical overview. Seminal discoveries related to the physiology of the ANS were made at the beginning of the 20th century. At that time, the English physiologist John N. Langley (1852-1925) introduced the terms sympathetic and parasympathetic nervous system and demonstrated their physiologic reactions. Walter Cannon (1871-1945), working at Harvard University, coined the term "fight or flight response" and suggested that stimulation of sympathetic nerves results in the release of a chemical agent related to epinephrine. Ulf von Euler (1905-1983) in Sweden eventually identified norepinephrine as this agent. Otto Loewi (1873-1961), working in New York, discovered that stimulation of the vagus nerve slowed the heart rate by releasing vagusstoff ("vagus substance”). Sir Henry Dale (1875-1968), at Cambridge
University, later discovered that this substance was acetylcholine. Walter R. Hess (1881-1973) at the University of Zurich established the influence of some areas of the brain on autonomic control. In fact, the Russian physiologist Ivan Pavlov (1849-1936) demonstrated the involvement of the cortex in autonomic processes with his classic experiments with dogs. Most of these researchers were awarded the Nobel Prize.

In 1925, Bradbury and Egglestone ${ }^{1}$ reported 3 patients with extremely low blood pressure upon standing (orthostatic hypotension $[\mathrm{OH}]$ ), along with other gastrointestinal, urogenital, and thermoregulatory abnormalities, but with no evidence of motor or cognitive impairment. This syndrome was eventually named pure autonomic failure (PAF). In the 1950s, it was recognized that autonomic dysfunction could be inherited (e.g., familial dysautonomia). ${ }^{2}$ In 1960, Shy and Drager ${ }^{3}$ described a group of patients with $\mathrm{OH}$, early urogenital dysfunction, and progressive neurodegeneration. Nine years later, Graham and Oppenheimer named this syndrome MSA. The American Autonomic Society was founded in 1990, and the first international symposium on the ANS was held that year in Nashville, Tennessee.

Recent developments. In recent decades, it has become increasingly recognized that not only MSA but also common neurodegenerative disorders, such as $\mathrm{PD}$ and dementia with Lewy bodies (DLB), may feature autonomic dysfunction, sometimes many years before motor or cognitive symptoms are evident. ${ }^{4}$ Autonomic testing and evidence of REM sleep behavior disorder can provide help to confirm these diagnoses and rule out other conditions. The recognition that PAF, as well as PD, DLB, and MSA, is associated with abnormal deposition of the protein $\alpha$-synuclein, and the fact that, after 15-20 years of documented follow-up, some patients with typical PAF develop parkinsonism or dementia, ${ }^{5}$ suggest that PAF might be part of the premotor spectrum of these disorders.

Researchers have recently reported the use of punch skin biopsy to measure $\alpha$-synuclein deposits in the epidermis. ${ }^{6}$ Potential biomarkers in CSF of

From the Dysautonomia Center (J.-A.P.), Department of Neurology, New York University School of Medicine, NY; the Department of Neurology (G.A.C.), Walter Reed National Military Medical Center, Bethesda, MD; the Department of Neurology (M.G.M.), Stanford University, Palo Alto, CA; and the Department of Neurology (A.L.), School of Medicine, University of Minnesota, MN.

Go to Neurology.org for full disclosures. Funding information and disclosures deemed relevant by the authors, if any, are provided at the end of the article. 
patients with synucleinopathies have been identified.? The capability for early diagnosis opens exciting opportunities for the development of future neuroprotective therapies in premotor stages of these disorders. The description of antibodies against the ganglionic acetylcholine receptor demonstrated that autoimmunity is another potential cause of autonomic dysfunction, leading to consideration of immunotherapy, such as IV immunoglobulins, in the treatment of these patients. ${ }^{8}$

In recent years, new symptomatic treatments for autonomic disturbances have been described and refined (e.g., droxidopa, a synthetic norepinephrine precursor, was recently approved by the Food and Drug Administration for the treatment of symptomatic neurogenic $\mathrm{OH})$. Advances in genetics, neuroimmunology, and neuroimaging warrant new, stimulating research and will provide therapeutic opportunities.

Autonomic testing. In addition to expertise in the physiopathology, clinical diagnosis, and management of these conditions, autonomic disorders specialists require a thorough knowledge of the performance and interpretation of autonomic testing. Commonly used autonomic tests assess sympathetic cardiovascular, parasympathetic cardiac (cardiovagal), and sudomotor functions.

Tests that assess sympathetic cardiovascular function include the beat-to-beat blood pressure profile during the Valsalva maneuver and the blood pressure and heart rate response to head-up tilt (or active standing if a tilt table is not available). Prolonged head-up tilt (20-45 minutes) may be needed in the evaluation of suspected neurally mediated (vasovagal) syncope. ${ }^{9}$ On certain occasions, pharmacologic provocation or lower body negative pressure may be used. Tests that assess vagal control of the sinus node (cardiovagal function) include the heart rate response to deep breathing (i.e., expiratory-inspiratory ratio) and the heart rate response to the Valsalva maneuver (i.e., Valsalva ratio). Sudomotor function tests include the thermoregulatory sweat test, which assesses the integrity of central and peripheral sudomotor pathways, and sudomotor axon reflex tests such as the quantitative sudomotor axon reflex test, which assesses the peripheral sympathetic cholinergic innervation of the sweat glands.

Determination of plasma catecholamines and vasopressin in the supine position and after 5-10 minutes of standing are also helpful to evaluate baroreflexmediated sympathetic activation. Microneurography can be used to perform direct recordings of muscle sympathetic nerve activity. Measurements of cerebral or limb blood flow, skin electrical conductance, or impedance cardiography may also be applied. Other tests indicated in some cases include blood volume measurement, nerve conduction studies, brain MRI, gastrointestinal motility and urodynamic studies, and polysomnography. Skin biopsy with assessment of intraepidermal nerve fiber density, abdominal fat aspirate, or sural nerve biopsy may also be needed.

Training opportunities in autonomic disorders. There are currently several fellowship programs available for those interested in pursuing a career in autonomic neurology. Most of these fellowships are accredited by the

Table

Autonomic disorders fellowship programs available in the United States

\begin{tabular}{|c|c|c|c|c|c|}
\hline Institution & $\begin{array}{l}\text { Years of } \\
\text { training }\end{array}$ & $\begin{array}{l}\text { Special } \\
\text { interests }\end{array}$ & Accreditation & Requisites & Contact information \\
\hline $\begin{array}{l}\text { Beth Israel } \\
\text { Deaconess Medical } \\
\text { Center/Harvard } \\
\text { Medical School } \\
\text { (Boston, MA) }\end{array}$ & 1 & $\begin{array}{l}\text { Peripheral neuropathy; } \\
\text { orthostatic intolerance; } \\
\text { neurodegenerative } \\
\text { disorders }\end{array}$ & ACGME & $\begin{array}{l}\text { IMG require ECFMG certification and USMLE step } \\
3 \text {; applicants must have completed a neurology } \\
\text { residency }\end{array}$ & $\begin{array}{l}\text { Dr. Roy Freeman } \\
\text { (Fellowship Director), } \\
\text { rfreeman@bidmc.harvard. } \\
\text { edu }\end{array}$ \\
\hline $\begin{array}{l}\text { Mayo Clinic } \\
\text { (Rochester, MN) }\end{array}$ & 1 & $\begin{array}{l}\text { Orthostatic } \\
\text { intolerance; } \\
\text { neurodegenerative } \\
\text { disorders }\end{array}$ & UCNS & $\begin{array}{l}\text { IMG require ECFMG certification; applicants should } \\
\text { be eligible for a license to practice medicine in } \\
\text { Minnesota }\end{array}$ & $\begin{array}{l}\text { Dr. Paola Sandroni } \\
\text { (Fellowship Director), } \\
\text { psandroni@mayo.edu }\end{array}$ \\
\hline $\begin{array}{l}\text { Medical College of } \\
\text { Wisconsin } \\
\text { (Milwaukee, WI) }\end{array}$ & $1-2$ & Pain processing & UCNS & IMG require ECFMG certification & $\begin{array}{l}\text { Dr. Thomas Chelimsky } \\
\text { (Fellowship Director), } \\
\text { tchelimsky@mcw.edu }\end{array}$ \\
\hline $\begin{array}{l}\text { NIH Clinical Center } \\
\text { (Bethesda, MD) }\end{array}$ & $1-3$ & $\begin{array}{l}\text { Neuroimaging; } \\
\text { neurodegenerative } \\
\text { disorders }\end{array}$ & UCNS & $\begin{array}{l}\text { IMG require ECFMG certification; applicants should } \\
\text { be eligible for a license to practice medicine in } \\
\text { Maryland }\end{array}$ & $\begin{array}{l}\text { Dr. David Goldstein } \\
\text { (Fellowship Director), } \\
\text { goldsteind@ninds.nih.gov }\end{array}$ \\
\hline $\begin{array}{l}\text { New York } \\
\text { University (New } \\
\text { York, NY) }\end{array}$ & $1-2$ & $\begin{array}{l}\text { Hereditary autonomic } \\
\text { disorders; } \\
\text { neurodegenerative } \\
\text { disorders }\end{array}$ & UCNS & $\begin{array}{l}\text { IMG require ECFMG certification; applicants must } \\
\text { have completed a neurology residency and should } \\
\text { be eligible for a license or limited permit to practice } \\
\text { medicine in New York }\end{array}$ & $\begin{array}{l}\text { Dr. Horacio Kaufmann } \\
\text { (Fellowship Director), } \\
\text { horacio.kaufmann@ } \\
\text { nyumc.org }\end{array}$ \\
\hline $\begin{array}{l}\text { Vanderbilt } \\
\text { University } \\
\text { (Nashville, TN) }\end{array}$ & $1-2$ & $\begin{array}{l}\text { Orthostatic } \\
\text { intolerance; } \\
\text { neurodegenerative } \\
\text { disorders }\end{array}$ & $\begin{array}{l}\text { UCNS } \\
\text { accreditation } \\
\text { pending }\end{array}$ & $\begin{array}{l}\text { IMG require ECFMG certification and their own } \\
\text { funding source }\end{array}$ & $\begin{array}{l}\text { Dr. Italo Biaggioni } \\
\text { (Fellowship Director), } \\
\text { italo.biaggioni@ } \\
\text { vanderbilt.edu }\end{array}$ \\
\hline
\end{tabular}

Abbreviations: ACGME = Accreditation Council for Graduate Medical Education; ECFMG = Educational Commission for Foreign Medical Graduates; IMG = International Medical Graduates; UCNS = United Council for Neurologic Subspecialties; USMLE = United States Medical Licensing Examination. 
United Council for Neurologic Subspecialties (UCNS), and a specific examination is required at the end of the program. The amount of time devoted to patient care, basic science research, or clinical research varies considerably between programs. Fellowship programs involve mostly outpatient clinic with occasional inpatient consultations. In order to obtain UCNS certification, fellows need to gain expertise in the performance and interpretation of autonomic testing. They also need to know how to interpret the results of other abovementioned ancillary tests.

Most of the academic centers currently offering fellowships are part of the Autonomic Disorders Consortium, a multicenter collaborative project (Harvard University, Mayo Clinic, NIH, New York University, and Vanderbilt University) that aims to define the natural history of autonomic disorders and conduct clinical trials. Most programs have a rolling admission process and require a license to practice medicine. The table summarizes the features of autonomic disorders fellowship programs currently available in the United States. In addition, in many other institutions, some degree of autonomic training is offered as part of neuromuscular, clinical neurophysiology, or movement disorders fellowship programs. Information on these other programs can be found on the Fellowship Directory of the American Academy of Neurology (https://www.aan.com/fellowship).

Career prospects in autonomic disorders. As of 2014, 27 autonomic specialists have been awarded the UCNS certification. This apparent low number is because the Autonomic Disorders certification started in 2009. It is expected that the number of autonomic disorder specialists will increase significantly in upcoming years due to the increasing awareness of these disorders and the advent of new therapeutic agents and a multitude of diagnostic procedures that require specialized clinical experience. A career in autonomic disorders would necessarily be located in a university-affiliated hospital or large neurology clinic, with opportunities for basic or clinical research, including clinical trials. An important role in the outpatient setting is the diagnosis and management of chronic autonomic disorders, as well as the differentiation of these disorders from disease mimics. Some of the most frequently seen problems are neurogenic $\mathrm{OH}$, vasovagal syncope, and sweating abnormalities. Both in the outpatient and impatient consultation settings, the autonomic specialist interacts with many specialties such as cardiology, gastroenterology, and urology. Cardiologists often consult on cases of postural tachycardia syndrome, which is probably a heterogeneous and multifactorial condition, rather than a primary autonomic disorder. ${ }^{10}$

Interaction with other neurologic subspecialties including behavioral neurology, movement disorders, sleep medicine, neuromuscular disorders, and epilepsy is also expected. For instance, patients with transient loss of consciousness (LOC) with a tentative diagnosis of epilepsy may be referred to rule out other causes of LOC, such as vasovagal syncope or psychogenic pseudosyncope.

Autonomic disorders is a burgeoning subspecialty that has the potential to contribute, from a privileged position, to the understanding of the causes, symptoms, and management of autonomic failure and the development of new treatments.

\section{AUTHOR CONTRIBUTIONS}

J.A.P.: drafting/revising the manuscript, study concept or design, study supervision. G.A.C.: drafting/revising the manuscript, study concept or design. M.G.M.: drafting/revising the manuscript, study concept or design. A.L.: drafting/revising the manuscript, study concept or design.

\section{ACKNOWLEDGMENT}

The authors thank Dr. Horacio Kaufmann for reviewing an earlier version of this manuscript.

\section{STUDY FUNDING}

No targeted funding reported.

\section{DISCLOSURE}

J.A. Palma receives funding support from the Dysautonomia Foundation, Inc., and has received compensation as a consultant/advisory board member for Lundbeck. G. Cook, M. Miglis, and A. Loavenbruck report no disclosures relevant to the manuscript. Go to Neurology.org for full disclosures.

\section{REFERENCES}

1. Bradbury S, Eggleston C. Postural hypotension: report of 3 cases. Am Heart J 1925;1:73-86.

2. Riley CM, Day RL, Greeley DMCL, et al. Central autonomic dysfunction with defective lacrimation: report of five cases. Pediatrics 1949;3:468-478.

3. Shy GM, Drager GA. A neurological syndrome associated with orthostatic hypotension: a clinical-pathologic study. Arch Neurol 1960;2:511-527.

4. Palma JA, Kaufmann H. Autonomic disorders predicting Parkinson's disease. Parkinsonism Relat Disord 2014;20 (suppl 1):S94-S98.

5. Kaufmann H, Nahm K, Purohit D, Wolfe D. Autonomic failure as the initial presentation of Parkinson disease and dementia with Lewy bodies. Neurology 2004;63:1093-1095.

6. Wang N, Gibbons CH, Lafo J, Freeman R. $\alpha$-Synuclein in cutaneous autonomic nerves. Neurology 2013;81:1604-1610.

7. Magdalinou N, Lees AJ, Zetterberg H. Cerebrospinal fluid biomarkers in parkinsonian conditions: an update and future directions. J Neurol Neurosurg Psychiatry 2014; 85:1065-1075.

8. Vernino S, Low PA, Fealey RD, Stewart JD, Farrugia G, Lennon VA. Autoantibodies to ganglionic acetylcholine receptors in autoimmune autonomic neuropathies. $\mathrm{N}$ Engl J Med 2000;343:847-855.

9. Wieling W, Thijs RD, van Dijk $\mathrm{N}$, Wilde AA, Benditt DG, van Dijk JG. Symptoms and signs of syncope: a review of the link between physiology and clinical clues. Brain 2009;132:2630-2642.

10. Benarroch EE. Postural tachycardia syndrome: a heterogeneous and multifactorial disorder. Mayo Clin Proc 2012; 87:1214-1225. 


\section{Neurology}

\section{Emerging Subspecialties in Neurology: Autonomic disorders \\ Jose-Alberto Palma, Glen A. Cook, Mitchell G. Miglis, et al. \\ Neurology 2015;84;e73-e75 \\ DOI 10.1212/WNL.0000000000001337}

\section{This information is current as of March 9, 2015}

\section{Updated Information \&} Services

References

Subspecialty Collections

Permissions \& Licensing

Reprints including high resolution figures, can be found at: http://n.neurology.org/content/84/10/e73.full

This article cites 10 articles, 3 of which you can access for free at: http://n.neurology.org/content/84/10/e73.full\#ref-list-1

This article, along with others on similar topics, appears in the following collection(s):

Autonomic diseases

http://n.neurology.org/cgi/collection/autonomic_diseases

Information about reproducing this article in parts (figures,tables) or in its entirety can be found online at:

http://www.neurology.org/about/about_the_journal\#permissions

Information about ordering reprints can be found online: http://n.neurology.org/subscribers/advertise

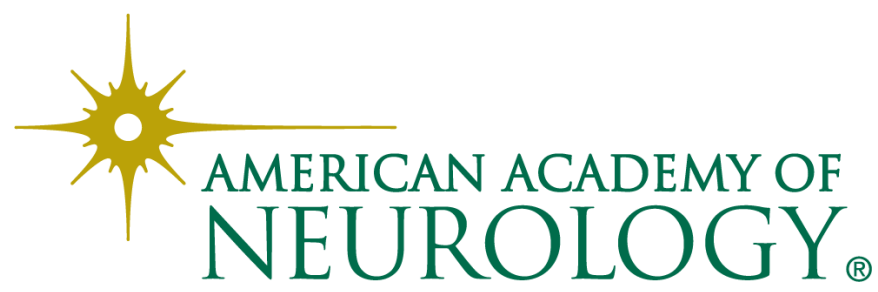

